\title{
48. Cytogenetic Similarities between the Formosan Serow (Capricornis swinhoi) and the Japanese Serow (Capricornis crispus)
}

\author{
By Hiroaki Soma,*) Hidemi KadA,*) Kunio Matayoshi,*) \\ Ming Tzong TsaI,*) Takashi KIYoKaWA,*) \\ Takeyoshi ITo,**) Kuan-Ping WANG,***) \\ Basil P. C. Chen,***) and Shu-Chu Tseng***) \\ (Communicated by Sajiro Makino, M. J. A., Sept. 12, 1981)
}

The subfamily Capricornis (serow) is divided into two species, Capricornis sumatrensis, and Capricornis crispus. Capricornis sumatrensis (the Sumatran serow) has 11 subspecies; Capricornis crispus consists of 2 subspecies which include Capricornis crispus crispus (Temminck) (the Japanese serow) and Capricornis crispus swinhoi (Gray) (the Formosan serow).

Dolan (1963) described the taxonomic relationship of the tribe Rupicaprini on the basis of morphological structures of skin and skull. Cytogenetic studies of the tribe Rupicaprini were made by some authors (Wurster and Benirschke, 1968; Gropp et al., 1970; Fischer and Höhn, 1972; Benirschke et al., 1972; Soma et al., 1980). The karyotype of Capricornis sumatrensis had a diploid number of $2 \mathrm{n}=$ 46 including five pairs of metacentrics and the metacentric sex chromosome, giving a Nombre Fondamental $(\mathrm{NF})=58$ (Fischer and Höhn, 1972), whereas those of Capricornis crispus crispus showed a number of $2 \mathrm{n}=50$ including five pairs of metacentrics and the $\mathrm{NF}=60$ (Benirschke et al., 1972). Accordingly, with regard to the difference in karyotypes between the Sumatran serow and the Japanese serow, further elucidation remains.

Capricornis swinhoi (the Formosan serow) has been treated as a subspecies of the Japanese serow: The former is not only smaller than the latter in size, but also the former looks more like the goral in appearance (Figs. 1-2). In addition, a comparison of the skull between the Japanese serow and the Formosan serow revealed a notable difference in the ratio of bone structure (Okada and Kakuta, 1970). The Formosan serow is now an endangered species in Taiwan. Until

*) Department of Obstetrics and Gynecology, Tokyo Medical College, Nishishinjuku 6, Shinjuku-ku, Tokyo 160, Japan.

**) Japan Serow Center, Gozaisho-Mountain, Mie Prefecture, Japan.

***) Taipei Zoo, 66 Chung-Shan N. Road, Sec. 3, Taipei, Taiwan 104. 

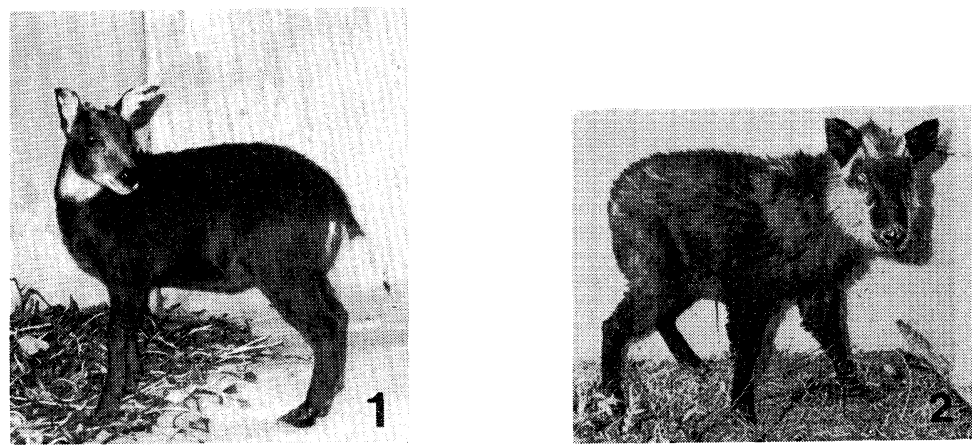

Figs. 1-2. 1: The female Formosan serow, Taipei Zoo. 2: The female Japanese serow, Japan Serow Center.

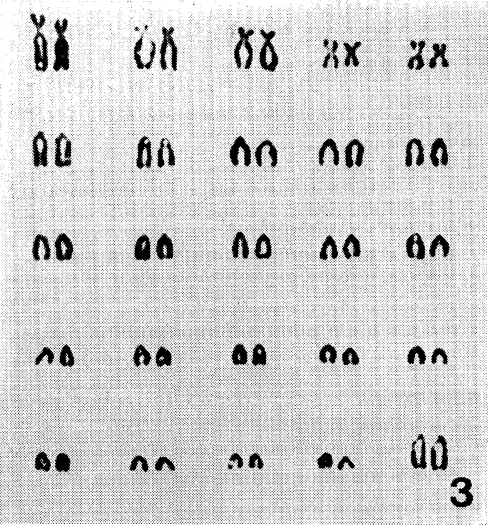

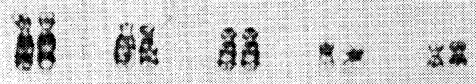

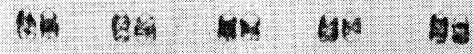
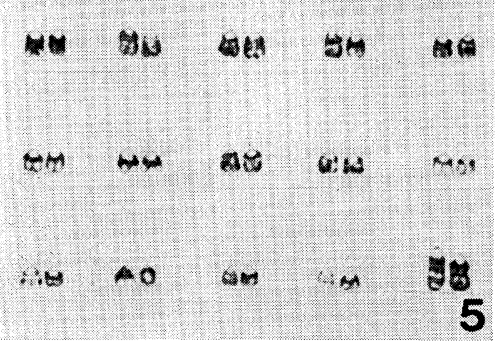
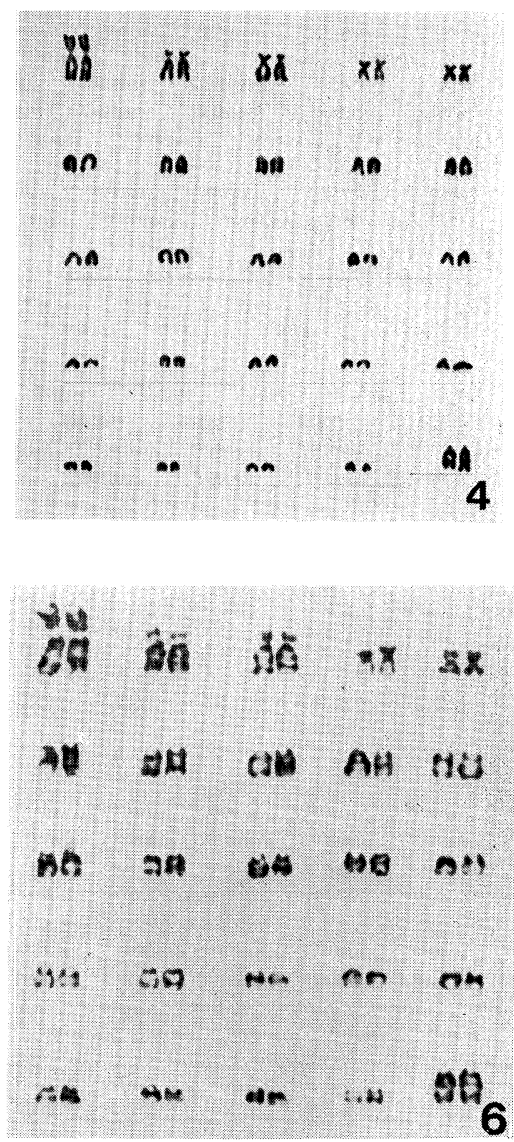

Figs. 3-6. 3: The karyotype of a female Formosan serow, $2 n=50$. 4: The karyotype of a female Japanese serow, $2 n=50$. 5: G-banding karyotype of a female Formosan serow. 6: G-banding karyotype of a female Japanese serow. 

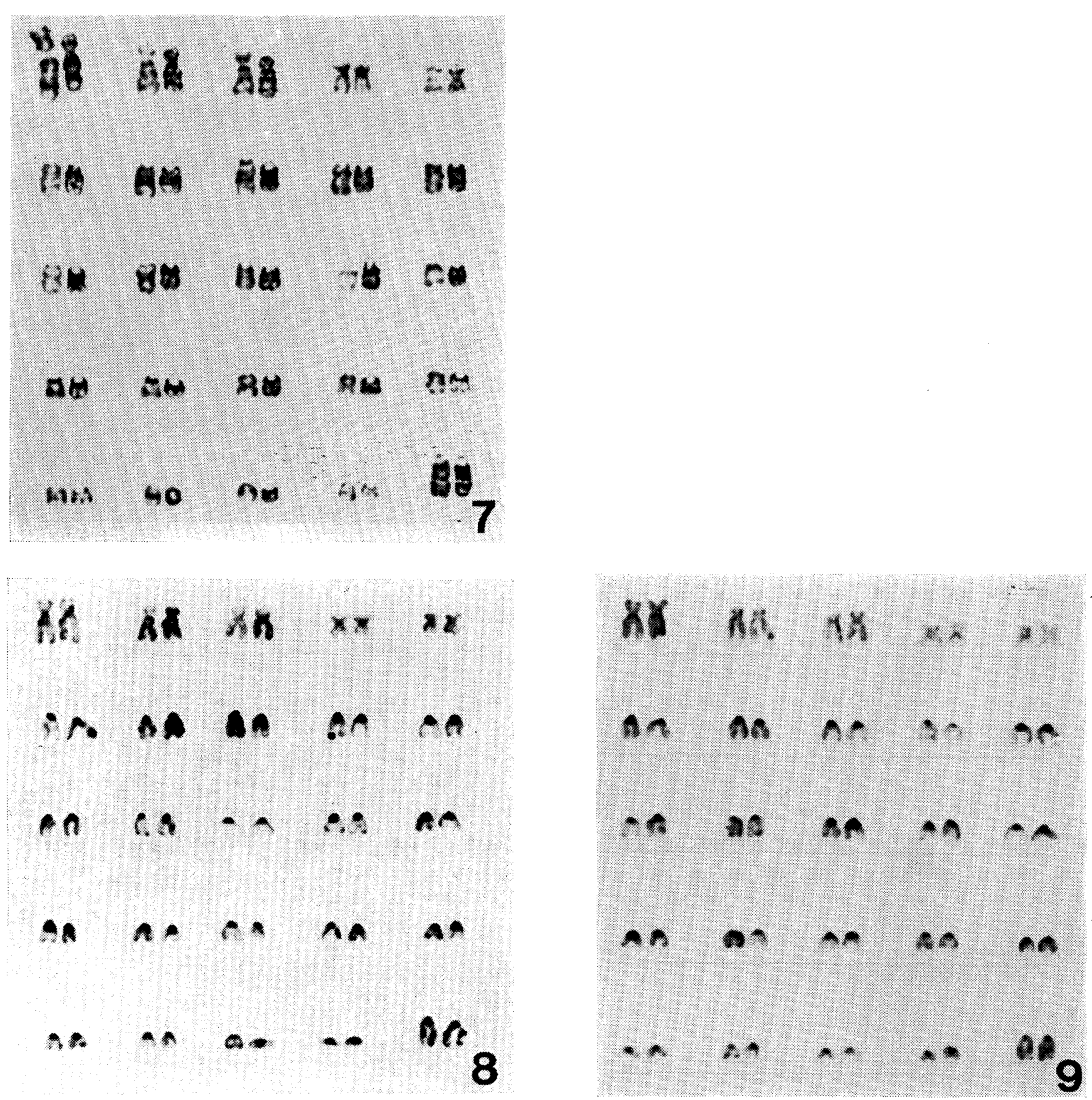

Figs. 7-9. 7: A comparison of G-banding karyotype between Japanese serow (left) and Formosan serow (right). 8: C-banding karyotype of a female Formosan serow. 9: C-banding karyotype of a female Japanese serow.

now the cytogenetic investigation of this serow has not been undertaken. Fortunately, we could obtain skin biopsies from a pair of Formosan serows at the Taipei Zoo, Taiwan, and the chromosomes were compared with those of the Japanese serow obtained from the Japan Serow Center, Gozaisho-Mountain with application of banding techniques.

Methods. Biopsy samples were twice obtained from both earlobes of a pair of Formosan serows at the Taipei Zoo in August, 1980 and in February, 1981. Although skin culture from one female Formosan serow was established after 23 days of incubation, skin cultures from a male serow failed to grow twice. As controls, skin culture from the earlobe of one female Japanese serow at the Japan Serow Center was grown after 15 days of incubation. After culturing, all air-dried preparations were stained by the conventional 
method and the trypsin-Giemsa technique (Seabright, 1972) as well as the C-banding technique (Sumner, 1972).

Results. All preparations of the female Formosan serow showed a diploid number of $2 \mathrm{n}=50$ with five pairs of metacentrics or submetacentrics and 20 pairs of acrocentrics including the sex chromosomes (Fig. 3). The karyotypes of the female Formosan serow are virtually identical to those found in the chromosomes of the female Japanese serow (Fig. 4). Therefore, the NF of this serow showed the same number of 60 . Our results regarding the chromosomes of the Japanese serow are very similar to those of the Japanese serow identified by Benirschke et al. (1972).

The Giemsa banding patterns on each chromosome pair of the Formosan serow and the Japanese serow are shown in Figs. 5 and 6. As illustrated in Figs. 5 and 6, Giemsa-banding analysis displayed a similar homologous pairing in the location of one or two bands. Gbanding patterns of both serows were similar in size and staining (Fig. 7). Moreover, it can be appreciated that the C-banding patterns of the chromosomes of both serows reveal similar constitutive heterochromatin adjacent to the centromeres of the acrocentrics (Figs. 8-9). The sex chromosomes of both serows are represented by larger acrocentrics with homologous staining.

Table I. Chromosomes of tribe Rupicaprini

\begin{tabular}{|c|c|c|c|c|c|}
\hline \multirow{2}{*}{ Species } & \multirow{2}{*}{ Authors } & \multirow{2}{*}{$\begin{array}{c}\text { Diploid } \\
\text { number } \\
2 n\end{array}$} & \multirow{2}{*}{$\frac{\text { Metacentrics (M) }}{\text { Acrocentrics (A) }}$} & \multirow{2}{*}{$\begin{array}{c}\text { Sex } \\
\text { chromosome }\end{array}$} & \multirow{2}{*}{$\mathrm{NF}$} \\
\hline & & & & & \\
\hline \multirow{2}{*}{$\begin{array}{l}\text { Capricornis } \\
\text { sumatrensis } \\
\text { (Sumatran serow) }\end{array}$} & \multirow{2}{*}{$\begin{array}{l}\text { Fischer and } \\
\text { Höhn } \\
\text { (1972) }\end{array}$} & \multirow[t]{2}{*}{46} & 10 & \multirow[t]{2}{*}{$M$} & \multirow[t]{2}{*}{58} \\
\hline & & & 34 & & \\
\hline \multirow{2}{*}{$\begin{array}{l}\text { Capricornis } \\
\text { crispus } \\
\text { (Japanese serow) }\end{array}$} & \multirow{2}{*}{$\begin{array}{l}\text { Benirschke, } \\
\text { Soma and } \\
\text { Ito }(1972)\end{array}$} & \multirow[t]{2}{*}{50} & 10 & \multirow[t]{2}{*}{$\mathrm{A}$} & \multirow[t]{2}{*}{60} \\
\hline & & & 38 & & \\
\hline \multirow{2}{*}{$\begin{array}{l}\text { Capricornis } \\
\text { swinhoi } \\
\text { (Formosan serow) }\end{array}$} & \multirow{2}{*}{$\underset{(1981)}{\text { Soma } e t} a l}$. & \multirow[t]{2}{*}{50} & 10 & \multirow[t]{2}{*}{ A } & \multirow[t]{2}{*}{60} \\
\hline & & & 38 & & \\
\hline \multirow{2}{*}{$\begin{array}{l}\text { Naemorhedus } \\
\text { goral } \\
\text { (Goral) }\end{array}$} & \multirow{2}{*}{$\underset{(1980)}{\text { Soma }}$ et $a l}$. & \multirow[t]{2}{*}{56} & 0 & \multirow[t]{2}{*}{$\mathrm{A}$} & \multirow[t]{2}{*}{56} \\
\hline & & & 54 & & \\
\hline \multirow{2}{*}{$\begin{array}{l}\text { Oreamnos } \\
\text { americanus } \\
\text { (Rocky Mountain } \\
\text { goat) }\end{array}$} & \multirow{2}{*}{$\begin{array}{l}\text { Wurster and } \\
\text { Benirschke } \\
\quad(1968)\end{array}$} & \multirow[t]{2}{*}{42} & 18 & $\mathrm{~A}$ & \multirow[t]{2}{*}{60} \\
\hline & & & 22 & $\mathbf{M}$ & \\
\hline \multirow{2}{*}{$\begin{array}{l}\text { Rupicapra } \\
\text { rupicapra } \\
\text { (Chamois) }\end{array}$} & \multirow{2}{*}{$\underset{(1970)}{\text { Gropp } e t} a l}$. & \multirow[t]{2}{*}{58} & 2 & A & \multirow[t]{2}{*}{60} \\
\hline & & & 54 & $M$ & \\
\hline
\end{tabular}

Discussion. The tribe Rupicaprini is taxonomically divided into four species; Naemorhedus (Goral), Capricornis (Serow), Oreamnos 
(Rocky Mountain goat) and Rupricapra (Chamois). The karyotypes of the 4 species of this group have been investigated (Wurster and Benirschke, 1968; Gropp et al., 1970; Fischer and Höhn, 1972; Benirschke et al., 1972; Soma et al., 1980). From these chromosomal analyses it has been confirmed that even though the diploid number of each species is different (Table I), NF in three species of Chamois (Wurster and Benirschke), Rocky Mountain goat (Gropp et al.) and the Japanese serow (Benirschke et al.) showed the same number of 60 , while the numbers of $\mathrm{NF}$ in the goral (Soma et al.) and the Sumatran serow (Fischer and Höhn) are 56 and 58, respectively.

Although the structural features of the metacentric elements in the Sumatran serow demonstrated by Fischer are similar to the chromosomes of the Japanese serow (Benirschke et al.), the sex chromosomes of the Sumatran serow include a large metacentric $X$, thereby the difference in the sex chromosome of the goral has been shown (Soma et al., 1980). It is desirable to clarify more completely the chromosomal pattern of the capricornis species in order to explain the reason for the reduction of $\mathrm{NF}$ and the presence of an unusual sex chromosome in the Sumatran serow.

As the first step of this research, we examined the karyotypes of the Formosan serow known as a subspecies of Capricornis crispus using two kinds of banding techniques in order to compare these with those of the Japanese serow.

It was demonstrated that the karyotypes of females Capricornis swinhoi and Capricornis crispus possessed not only the same diploid number of $2 n=50$ consisting of 10 metacentrics and 40 acrocentrics including the sex chromosome, but also the chromosome features of both serows were identical in banding patterns. The NF of the Formosan serow is 60 .

Even though there exists some difference in the morphological appearance and skull structure between both serows, it can be estimated that they have had the same genetic evolution. Therefore, further chromosomal information on the Sumatran serow species with the use of banding analysis is highly desirable.

Acknowledgements. We wish to thank Dr. K. Benirschke, Research Director, San Diego Zoo and Dr. S. Makino, Emeritus Professor, M. J. A., Hokkaido University, for their kind guidance and critical reading of this paper.

\section{References}

Benirschke, K., Soma, H., and Ito, T. (1972) : The chromosomes of the Japanese serow, Capricornis crispus (Temminck). Proc. Japan Acad., 48, 608-612. 
Dolan, J. M. (1963) : Beitrag zur systematischen Gliederung des Tribus Rupicaprini Simpson, 1945. Zeit. zool Syst. Evolutionsforsch., 1, 311-407.

Fischer, H., and Höhn, H. (1972) : Der Karyotype des Serau (Capricornis sumatraensis, Bechstein, 1799). Giessener Beitr. Erbpath. Zuchthyg., 4, 8-15.

Gropp, A., Giers, D., Fernandez-Donoso, R., Tiepolo, L., and Fraccaro, M. (1970) : The chromosomes of the chamois (tribe Rupicaprini Simpson). Cytogenetics, 9, 1-8.

Okada, Y., and Kakuta, T. (1970) : Studies on the Japanese serow, Capricornis crispus (Temminck). Soc. Preserv. Japanese Serow Suzuka Mountain (10th Anniversary Volume), pp. 1-7.

Seabright, M. (1972): The use of proteolytic enzymes of the mapping of structural rearrangements in the chromosomes of man. Chromosoma, 36, 204-210.

Soma, H., Kada, H., Matayoshi, K., Kiyokawa, T., Ito, T., Miyashita, M., and Nagase, K. (1980) : Some chromosomal aspects of Naemorhedus goral (goral) and Procapra gutturosa (Mongolian gazelle). Proc. Japan Acad., 56B, 273-277.

Sumner, A. T. (1972) : A simple technique for demonstrating centrometric heterochromatin. Exptl. Cell Res., 75, 304-306.

Wurster, D. H., and Benirschke, K. (1968): The chromosomes of the Rocky Mountain goat (Oreamnos americanus). Mammal. Chrom. Newsl., 9, 80-81. 